their study under the auspices of the Scientists Institute for Public Information.

- Alastair Hay adds : At the time of the Seveso explosion, 150 women resident in the area were in the first trimester of pregnancy. Most of the women applied for a therapeutic abortion when informed of the teratogenic properties of dioxin. Following examination by health officials of 730 pregnant women formerly resident in the contaminated area, only 29 have had thc operation. The foetuses removed from these women are currently being examined for any signs of abnormality.

Professor Francesco Cefis of the Instituti Clinici di Perfezionamento in Milan, and Professor Alfred Gropp, Head of the Pathology Depjartment of Lübeck Medical School in Germany, are in charge of the investigations. Neither would comment last week on the results of their observations so far. Only five of the 29 foetuses have been examined and Profesor Cefis estimated that it would take another two months to complete the study. By then women who were in the earlier stages of pregnancy in July will be six or seven months pregnant-too late for an abortion to be performed.

The rate of spontaneous abortions in the Seveso area is reported to have increased to twice the Italian national average since July. The rate of miscarriage was reported to have increased similarly in Vietnam following spraying with the herbicide 2,4,5-T. Both the trichlorophenol discharged at Seveso and the 2,4,5-T used in Vietnam contained dioxin. The Vietnamese authorities maintain that dioxin was responsible for the miscarriages

\title{
Towards anticipating disaster
}

In Britain last week the Insurance Technical Bureau (ITB), which leading insurance groups established in 1972 as a non-profit making organisation with "technical expertise in the field of industrial loss prevention". demonstrated 'Anticipator', a new system designed to alert managers of chemical plants to potential hazards in their site installations.

One of the recommendations made by the 1974 Court of Inquiry into the Flixborough disaster was that some form of recorder should be made available to monitor operating conditions in industrial installations. This would perform a function similar to that of the 'black box' flight recorder in aircraft. 'Anticipator' is a sophisticated monitoring system with its own computer which will register information about pressure, temperature, flow rates, gas leaks, vibrations and other factors relevant to the safe operation of a chemical plant. It can be preprogrammed to record only data which fall outside normal working parameters. making interpretation a relatively simple process.

The designers argue that incidents usually "cast their shadows before them", and feel certain that Anticipator would have prevented accidents such as those at Flixborough and Seveso. With the primary research and development work now completed at a total cost of $£ 50,000$, the ITB propose to find a commercial concern to develop the system for marketing. The trouble is, the biggest firms do their own monitoring, and the smaller ones may not be able to afford the new device.

Alastair Hay which they recorded.

Meanwhile, the scientific commission responsible for formulating a policy to decontaminate the area containing dioxin has still not agreed upon methods to be employed. Frustration at the apparent inactivity has been expressed both by experts anxious to begin the work of decontamination, and by former residents of the area who last week tore down protective fences in protest at the delay.

The work of the commission has been hampered by the disagreement among experts concerning the amount of dioxin to be dealt with. Dr Donald Lee of the Plant Pathology Laboratory at Harpenden, UK, suggests that $130 \mathrm{~kg}$ of dioxin was released in the explosion, and Professor Samuel Ep- stein of the University of Illinois, considers the figure of $300 \mathrm{lb}$ of dioxin to be "about right". But a group of chemical engineers invited by the commission to submit a programme for decontamination estimate that $1-3 \mathrm{~kg}$ of dioxin was released, a figure based on results obtained from a simulation of the explosion.

The two top officials of ICMESA, who after being arrested and charged with culpably causing a disaster were released on bail to supervise decontamination work within the ICMESA plant, have since been rearrested and criminal proceedings have begun. The criminal prosecution will be conducted at the same time as the civil proceedings brought against HoffmanLa Roche, ICMESA's owners, by the Italian authorities.

\section{Manoeuvring for agreement}

The EEC's Council of Research Ministers met in Brussels last week to discuss once again the Joint European Torus (JET), the Community's fusion project, and the research programme for the Community's Joint Research Centre (JRC). Chris Sherwell reports

So near and yet so far. The EEC now looks sufficiently close to agreement on the site for JET that the small step the Council of Research Ministers took at their meeting last week may in retrospect come to look like a giant leap for the Community. But because there is still ample scope for more than one hitch, the prospect could be as much for a leap backwards as a leap for- wards.

On paper the progress that everyone is keen to say really did occur in Brussels certainly looks very slight. The Council reached just one firm decision with any consequence in terms of action or expenditure. This was that the Community's fusion programme, which is undertaken by a number of associated laboratories in the member states but does not include JET, could go ahead for another four years.

To call that insignificant, though, is to reckon without the intricacies and nuances of Community deliberations. Until now there has been no agreement on expenditure for the full five years of the fusion programme. When the programme first came up for discussion last December, Italy refused consent, saying she could not agree without a decision on a site for JET. She modified this position at a February Council meeting, allowing just one year's expenditure. In the view of one senior official in Brussels, therefore, the absence last week of continued further blocking of the programme from Italy means that the decision can be interpreted as a positive sign for JET.

What changed Italy's mind? The answer is to be found in the way the JET argument has developed. Italy's concern has always been principally over the fate of Ispra, one of the four establishments constituting the JRCthe others are in Germany, Belgium and the Netherlands, but Ispra is the largest with two-thirds of the JRC staff. By the last Council meeting in October it had hecome clear that progress on 